\title{
PERSONAL QUALITIES OF LEARNING FACILITATORS IN ADULT AND CONTINUING EDUCATION: OPINION OF ADULT EDUCATORS IN LATVIA AND LITHUANIA
}

\author{
Vaiva Zuzevičiūtè \\ Mykolas Romeris University \\ Svetlana Surikova \\ University of Latvia
}

\begin{abstract}
The paper highlights the key findings from a comparative study conducted in 20112012 using the project "Qualified to Teach" - QF2TEACH first wave questionnaire (www.qf2teach.eu). The questionnaire was structured in nine domains: personal qualities; interpersonal behaviour and communication with learners; cooperation with the external environment; planning and management; access and progression of learners; subject-related, specialist domain; monitoring and assessment of learning processes; didacticalmethodological domain; personal development and reflection. In present paper the main results of transnational survey in Latvia and Lithuania are analysed in order to evaluate the importance of certain personal qualities of learning facilitators in adult and continuing education from current and future perspectives as well as to identify the main future-required personal qualities. The study results indicated that open mindedness, optimism, emotional stability, sincerity, pro-activity, flexibility, sociability, tolerance, and morality (ethics) have been named both by the Latvian and Lithuanian adult educators as the main future-required personal qualities of the learning facilitators in adult and continuing education.
\end{abstract}

Keywords: Adult and continuing education (ACE), adult educator, adult learner, adult learning, adult learning professional, learning facilitator, personal qualities.

\section{Introduction}

Bron and Jarvis (2008) defined adult education as "a discipline which studies adults' opportunities and conditions for learning and fostering, as well as for their development, so that through the process of learning, people will develop themselves, change their lives and possibly influence each other" (p. 35). According to Jarvis (2012), "adult educators have sometimes tended to confuse adult education and adult learning", in fact, "since it is now recognised that selfdirected learning is a common occurrence, it is important to regard education and learning as conceptually distinct phenomena" (p. 8). Well-qualified adult educators are needed in order "to achieve both a quantitative expansion and a qualitative improvement of adult learning activities" (Nuissl \& Lattke, 2008, p. 7). Furthermore, according to Deggs and Miller (2011), "adult educators must employ new paradigms if they are to be successful in positively influencing the amount and value of social capital" (p. 29). Therefore the professional development and the quality of adult learning professionals is a hot topic of discussion in Europe (Bernhardsson \& Lattke, 2011; Gartenschlaeger, 2009; Nuissl \& Lattke, 2008; Research voor Beleid, 2008, 2010; Teresevičienė \& 
Zuzevičiūtè, 2009, etc) and around the world (Coryell, 2013; Deggs \& Miller, 2011; Ellis \& Richardson, 2012; Nuissl \& Egetenmeyer, 2010, etc).

The purpose of this paper is to present the main empirical findings of the transnational comparative study conducted in Latvia and Lithuania in 2011-2012 using the research tool developed in the frame of the project "Qualified to Teach" (QF2TEACH). Firstly, a methodology of the QF2TEACH study will be discussed describing the main methodological statements of the study (e.g., the structure of the QF2TEACH first wave questionnaire). Secondly, the national contexts and samples of the transnational comparative study in Latvia and Lithuania will be presented. Thirdly, due to limitations to the scope of the paper, only some part of results will be analysed in order to evaluate the importance of certain personal qualities of the ACE learning facilitators from current and future perspectives as well as to identify the main future-required personal qualities. Finally, the main findings will be summarised and general conclusions will be made.

\section{Methodology of the QF2TEACH Study}

The project "Qualified to Teach" - QF2TEACH (www.qf2teach.eu) is an international project funded by the Leonardo da Vinci programme of the European Union. It was conducted in 2009-2011 by a consortium of eight European countries (Germany, Italy, Poland, Romania, Sweden, Switzerland, United Kingdom, Netherlands). The project dealt with competences and qualifications of the ACE learning facilitators. During the initial discussions in the project concerning the used terms, the term 'teacher' was rejected as too narrow. It was agreed among the partners that the term should be broad enough to cover more roles than just "teachers" in the traditional sense, and at the same time it should be focused enough to highlight only one particular section in the variety of imaginable professional roles in the field of adult education, namely those professionals who work in direct contact with the adult learners. In the end, the term 'learning facilitator' was considered appropriate by the project partners to fulfil these requirements (Bernhardsson \& Lattke, 2011:19-21).

The term ACE learning facilitators refers to a variety of professional roles such as teachers, trainers, coaches, guidance and counseling staff and others. This means adult education course teachers, trainers in companies and in general all people, whose professional activity takes place in direct contact with adult learners and consists in initiating, supporting and monitoring learning processes of adults (Bernhardsson \& Lattke, 2011:66).

The main aim of QF2TEACH was to determine the core competences needed by the ACE learning facilitators today and in the future by conducting a Delphi survey in two waves based on the assessments and opinions of the involved experts. The second aim of the QF2TEACH project was to develop a researchbased concept for a transnational qualification framework for the ACE learning 
facilitators, which is linked to the existing overarching European Qualification Framework (EQF), in an effort to determine visible and comparable qualification levels of adult professionals throughout Europe (Bernhardsson \& Lattke, 2011:6).

In the first phase of the QF2TEACH project the research instrument (the first wave questionnaire) was developed and structured in three parts. The first part comprised questions on competences of the ACE learning facilitators. The first part of the questionnaire, concerning competences of the ACE learning facilitators, was structured in nine domains: personal qualities; interpersonal behaviour and communication with learners; cooperation with the external environment; planning and management; access and progression of learners; subject-related, specialist domain; monitoring and assessment of learning processes; didactical-methodological domain; personal development and reflection. In the second part the respondents were asked to give their opinions on selected aspects of the development of the occupational and professional field. Aim of this part was to explore the target group's views on policy aspects (e.g., regulation of the field, introduction of standards) relating to the professionalisation of the ACE field. In the third part, the respondents were asked to give some personal particulars (Bernhardsson \& Lattke, 2011:23-25).

This paper gives an analysis of the main results of the transnational comparative study conducted in 2011-2012 in Latvia and Lithuania using the QF2TEACH first wave questionnaire with a special emphasis on the personal qualities of the ACE learning facilitators. An empirical quantitative survey with some elements of qualitative study was employed for this study.

\section{National Contexts and Samples of the Research}

In Latvia, QF2TEACH first wave questionnaire on the core competences of ACE learning facilitators was used in the frame of the study "Identification and analysis of new challenges and solutions that have influence on engagement and reintegration of adults (18-24 years) in lifelong learning" funded by ESF project "Support to research in educational field" (sub-activity 1.2.2.3.2.), project No 011/0011/1DP/1.2.2.3.2/11/IPIA/VIAA/001. The original questionnaire was translated into Latvian and Russian and created as a web-based survey tool (i.e. online questionnaire) using Google forms. The translated questionnaires were sent to 6 voluntary experts to provide feedback on it's adaptation to Latvian context. In October 2011 the email invitation of participating in the web-based survey was sent out to 155 adult educators from the field of second chance education (evening shift schools). In February 2012 Latvian survey yielded a total of 64 respondents for a response rate of $41.3 \%$. The majority of adult educators was female $(\mathrm{n}=61 / 95 \%)$ and the minority of them was male $(\mathrm{n}=3 / 5 \%)$. The respondents were aged under $40(n=21 / 33 \%) ; 40-50(n=18 / 28 \%)$; above 50 $(n=25 / 39 \%)$. 
In Lithuania, QF2TEACH original questionnaire was shortened and then translated in Lithuanian. The paper version of the questionnaire was shared among the Lithuanian respondents (e.g., adult educators from the different fields of adult education: language, music, tourism, natural sciences, etc). Lithuanian survey yielded a total of 108 respondents. From them 93 were females and 15 were males. The work experience of Lithuanian respondents was under 10 years $(\mathrm{n}=60 / 56 \%) ; 10-19$ years $(\mathrm{n}=26 / 24 \%) ; 20-29$ years $(\mathrm{n}=10 / 9 \%)$; above 30 years $(\mathrm{n}=11 / 10 \%)$; unknown $(\mathrm{n}=1 / 1 \%)$.

\section{Empirical Findings of the Research (Comparative Analysis)}

The empirical findings concerning the personal qualities (one of the nine domains) of the first wave questionnaire are presented in brief comparative discourse in this section of the paper. The obtained quantitative data were processed and analysed using SPSS 17.0 software (frequencies, crosstabs, means report, Mann-Whitney $U$ test). Mann-Whitney $U$ test was run to determine if there were statistically significant differences in respondents' view regarding the personal qualities of ACE learning facilitator today (in 2011-2012, see Table 1) and in the future (in 2015, see Table 2) between Latvian and Lithuanian adult educators.

\section{Personal qualities of ACE learning facilitator: Current perspective}

The respondents were asked to indicate how important are certain personal qualities in their view to be a competent ACE learning facilitator answering the closed-ended question First of all we deal with the relevance of competences in a field we named "personal qualities". ACE learning facilitators should be... (Please choose the appropriate response for each item.) Today this is... For each item a rating had to be given on a 6-point Likert scale from 'irrelevant' (score 1) up to 'indispensable' (score 6). As it is shown in Table 1, from the current perspective the Latvian adult educators rated emotionally stable as the first quality of the competent ACE learning facilitator followed by be attentive and be authentic (the data on be empathetic was missing in the case of Latvia). On the other hand, be extroverted and be altruistic were rated low. In the case of Lithuania, be extroverted and be attentive were rated as top qualities followed by be emotionally stable and be open minded. On the other hand, altruistic was the least rated quality (see Table 1). The cross comparison of the countries shows that the Latvian respondents have rated higher on authentic and humorous when compared with Lithuania. From the current perspective, the personal qualities such as attentive, extroverted, emotionally stable, and open minded were rated by the Lithuanian adult educators higher (mean from 3.58 up to 5.30; mode $=4$ or 6 ) in comparison with the Latvian adult educators (mean from 3.28 up to $4.64 ;$ mode $=3 ; 4$ or 5 ). However, two qualities such as be attentive and be emotionally stable were included in Top 3 both by the Latvian and Lithuanian 
adult educators. Similar trends can be seen in previously conducted study also. During the first wave of Delphi study conducted in 2009-2010 in the frame of the QF2TEACH the highest rating was given to the item 'be open minded' (mean=5.41) followed by item 'be emotionally stable' (mean=5.06) and 'be attentive' (mean=5.05) (Bernhardsson \& Lattke, 2011:83).

Table 1

Personal qualities: ACE learning facilitators should be... Today this is...

\begin{tabular}{|c|c|c|c|c|c|c|}
\hline \multirow{3}{*}{$\begin{array}{l}\text { Personal } \\
\text { qualities }\end{array}$} & \multicolumn{2}{|c|}{ Means Report } & \multicolumn{4}{|c|}{ Mann-Whitney U test } \\
\hline & \multirow{2}{*}{ Latvia } & \multirow{2}{*}{ Lithuania } & \multicolumn{2}{|c|}{ Mean rank } & \multirow{2}{*}{ U-value } & \multirow{2}{*}{$\begin{array}{c}\text { Asymp. } \\
\text { Sig. }\end{array}$} \\
\hline & & & Latvia & Lithuania & & \\
\hline Be empathetic & $\mathrm{N} / \mathrm{A}$ & 4.04 & $\mathrm{~N} / \mathrm{A}$ & 52.50 & N/A & N/A \\
\hline Be authentic & 4.42 (3) & 4.31 & 83.08 & 83.76 & 3237,000 & 0.925 \\
\hline Be humorous & 4.23 & 4.11 & 87.92 & 84.85 & 3301,000 & 0.681 \\
\hline Be attentive & $4.48(2)$ & $5.30(1)$ & 56.34 & 102.47 & 1525,500 & 0.000 \\
\hline Be extroverted & 3.83 & $5.30(1)$ & 47.20 & 108.62 & 941,000 & 0.000 \\
\hline Be altruistic & 3.28 & 3.58 & 77.75 & 90.18 & 2896,000 & 0.101 \\
\hline Be open minded & 4.00 & $5.03(3)$ & 55.95 & 102.70 & 1501,000 & 0.000 \\
\hline $\begin{array}{l}\text { Be emotionally } \\
\text { stable }\end{array}$ & 4.64 (1) & $5.27(2)$ & 59.52 & 101.84 & 1729,500 & 0.000 \\
\hline
\end{tabular}

The further analysis reveals that there is no significant difference in the mean rank scores obtained on be authentic $(p=0.925)$, be humorous $(p=0.681)$, and be altruistic $(p=0.101)$. Although the qualities as be authentic and be humorous were rated higher by Latvians in comparison with Lithuanians. However, there is the most significant difference $(p=0.000)$ in rating of four personal qualities (namely attentive, extroverted, open-minded, emotionally stable) between Latvian and Lithuanian respondents (see Table 1). As it was mentioned previously these personal qualities were rated higher by the Lithuanian adult educators when compared with the Latvian adult educators.

\section{Personal qualities of ACE learning facilitator: Future perspective}

The second question asked for the future importance of each personal quality. The adult educators were asked to evaluate the future importance answering the closed-ended question We deal with the relevance of competences in a field we named "personal qualities". ACE learning facilitators should be... (Please choose the appropriate response for each item.) In 2015 this will be... The respondents were asked to indicate if the respective item would be 'less important' (score 1), 'equally important' (score 2) or 'more important' (score 3) in 2015. As it is shown in Table 2, in the case of Latvia top priority was given to emotionally stable followed by authentic and attentive rating from the perspective of future importance. On the other hand, altruistic was given least priority. In the case of Lithuania, highest priority was given for be emotionally 
stable followed by open mindedness and attentiveness. On the other hand, the qualities such as altruistic and humorous were given low preference (see Table 2).

Table 2

Personal qualities: ACE learning facilitators should be... In 2015 this will be...

\begin{tabular}{|c|c|c|c|c|c|c|}
\hline \multirow{3}{*}{$\begin{array}{l}\text { Personal } \\
\text { qualities }\end{array}$} & \multicolumn{2}{|c|}{ Means Report } & \multicolumn{4}{|c|}{ Mann-Whitney U test } \\
\hline & \multirow{2}{*}{ Latvia } & \multirow{2}{*}{ Lithuania } & \multicolumn{2}{|c|}{ Mean rank } & \multirow{2}{*}{ U-value } & \multirow{2}{*}{$\begin{array}{l}\text { Asymp. } \\
\text { Sig. }\end{array}$} \\
\hline & & & Latvia & Lithuania & & \\
\hline Be empathetic & $\mathrm{N} / \mathrm{A}$ & 2.05 & $\mathrm{~N} / \mathrm{A}$ & 52.50 & N/A & N/A \\
\hline Be authentic & $2.53(2)$ & 2.10 & 105.32 & 73.53 & 2123,500 & 0.000 \\
\hline Be humorous & 2.34 & 1.99 & 102.29 & 76.26 & 2381,500 & 0.000 \\
\hline Be attentive & $2.52(3)$ & $2.36(3)$ & 94.37 & 81.00 & 2888,500 & 0.049 \\
\hline Be extroverted & 2.16 & 2.35 & 76.78 & 90.76 & 2834,000 & 0.035 \\
\hline Be altruistic & 2.05 & 1.90 & 91.23 & 81.20 & 2961,000 & 0.136 \\
\hline Be open minded & 2.48 & $2.50(2)$ & 83.86 & 84.89 & 3287,000 & 0.879 \\
\hline $\begin{array}{l}\text { Be emotionally } \\
\text { stable }\end{array}$ & $2.67(\mathbf{1})$ & $2.52(1)$ & 92.10 & 80.67 & 2905,500 & 0.085 \\
\hline
\end{tabular}

From the perspective of future importance (see Table 2), five qualities such as authentic, humorous, attentive, altruistic, and emotionally stable were rated by the Latvian respondents higher (mean from 2.05 up to 2.67) in comparison with the Lithuanian respondents (mean from 1.90 up to 2.52). The Lithuanian respondents rated higher in the case of extroverted and open minded than the Latvian respondents.

The calculated $p$-value indicated that there is no significant difference in the mean rank scores obtained on be altruistic $(p=0.136)$, be open minded $(p=0.879)$, and be emotionally stable $(p=0.085)$. However, there are the most significant $(p=0.000)$ and significant $(p=0.049 ; p=0.035)$ differences among the countries in mean rank scores obtained on be authentic, be humorous, be attentive, and be extroverted (see Table 2).

The majority of the Lithuanian respondents (from $54.3 \%$ up to $72.9 \%$ ) evaluated the future importance of empathetic, authentic, humorous, attentive, extroverted, and altruistic as 'equally important', so the importance of these qualities will be the same in the future. On the other hand, the qualities such as be open minded and be emotionally stable have been rated as 'more important' in 2015 by the majority of Lithuanian respondents (from 54.3\% up to 55.8\%). In 2012, for instance, the Lithuanian respondents noted that:

- In 2015 it will be very important to be open minded, because there will be more people from other countries, different ages, therefore learning materials will have to be attractive and suited for the characteristics of learners.

- In the future it will be very important to communicate well, to be emotionally stable, to adapt to changing environment fast. 
The majority of Latvian respondents (from $53.1 \%$ up to $67.2 \%$ ) evaluated the future importance of authentic, attentive, open minded, and emotionally stable as 'more important' in 2015. The majority of Latvian respondents (from 56.3\% up to $73.4 \%$ ) evaluated the future importance of humorous, extroverted, and altruistic as 'equally important'.

Similar trends can be seen in previously conducted study also. According to the results of the first wave of Delphi study conducted in 2009-2010 in the frame of the QF2TEACH more than $25 \%$ of the respondents thought that the personal qualities of ACE learning facilitators such as be open minded and be emotionally stable will be more important in 2015 (Bernhardsson \& Lattke, 2011:82-83).

\section{Main future-required personal qualities of ACE learning facilitator}

The respondents were asked to answer the open-ended question If there are any personal qualities that you think will become more important in the future, please indicate why. Please write your answer. The main future-required personal qualities named by the Latvian and Lithuanian respondents are highlighted in Table 3.

Personal qualities that will become more important in the future: Some expressions

\begin{tabular}{|c|c|}
\hline By the Latvian respondents & By the Lithuanian respondents \\
\hline $\begin{array}{l}\text { I think it will be important to be open minded, to } \\
\text { search and use information wisely. I think that an } \\
\text { ability to learn something new, thirst for knowledge, } \\
\text { inquisitiveness, curiosity, erudition will be } \\
\text { important in the future. } \\
\text { It will be important to adapt quickly to the new } \\
\text { requirements and new situations, be flexible; be } \\
\text { emotionally prepared for the challenges and be able } \\
\text { to defy the moments of weaknesses. In my opinion, } \\
\text { emotional stability and patience will become more } \\
\text { important. } \\
\text { From my point of view, the qualities such as to be } \\
\text { fair, authentic, sociable will be more important } \\
\text { because a community will lead to an outbreak of } \\
\text { emotions and adult learners will look for treatment } \\
\text { based on humanity, sincerity, empathy, tolerance, } \\
\text { and understanding. Furthermore a loyalty, } \\
\text { responsiveness, knowledge of teaching ethics, the } \\
\text { ability to listen and understand the adult learners' } \\
\text { needs, the ability to explain, motivate will become } \\
\text { more important. } \\
\text { I think that a personal charisma, intelligence, } \\
\text { optimism, sense of humor, creativity, pro-activity, } \\
\text { self-confidence, and responsibility will be crucially } \\
\text { important in the future. }\end{array}$ & $\begin{array}{l}\text { I think that honesty will become more important. At } \\
\text { the moment, however, honesty is disappearing, we } \\
\text { are all hiding behind masks. } \\
\text { I think that an ability to communicate, optimism, } \\
\text { sincerity are crucially important. Life is becoming } \\
\text { more complicated, not easier. We all have a lot of } \\
\text { desires and we all rush somewhere. } \\
\text { I think we will have to work more in teams, and less } \\
\text { individually. It is important to be emotionally stable, } \\
\text { to cooperate well, be sociable, to make joint } \\
\text { decisions, to share experiences, and be pro-active. } \\
\text { I think that an ability to plan time well, to provide } \\
\text { arguments for one's opinions and to be constructive } \\
\text { in providing critical comments are important. I think } \\
\text { that a sincerity and attentiveness are important. } \\
\text { I think it is important to be a professional in one's } \\
\text { field and be able to trigger enthusiasm of learners. } \\
\text { Also, open mindedness and morality are important. } \\
\text { Because of the increasing competition such } \\
\text { competencies as ability to choose, planning, } \\
\text { tolerance, flexibility, fast decision making, accepting } \\
\text { changes will become more important. }\end{array}$ \\
\hline
\end{tabular}


Both the Latvian and Lithuanian respondents have named open mindedness, optimism, emotional stability, sincerity, pro-activity, flexibility, sociability, tolerance, and morality (ethics) as the future-required personal qualities of the ACE learning facilitators. According to the results of the first wave of Delphi study conducted in 2009-2010 in the frame of the QF2TEACH the respondents thought that the personal qualities such as be enthusiastic, be passionate (Italy \& United Kingdom); be creative (Poland); be self-confident (Romania); be intelligent (Switzerland) will become more important in future (Bernhardsson \& Lattke, 2011:82-83). Similar trends can be seen in Latvian case too.

\section{Conclusions}

The main results of the transnational comparative study conducted in 2011-2012 in Latvia and Lithuania using the QF2TEACH first wave questionnaire have been analysed in this paper with a special emphasis on the personal qualities of the ACE learning facilitators. The key findings of the quantitative study showed that from the current perspective there was no significant difference in adult educators' opinions on be authentic, be humorous, and be altruistic between Latvian and Lithuanian respondents. Although the qualities as be authentic and be humorous were rated higher by Latvians. However, there was the most significant difference in rating of qualities such as be attentive, be extroverted, be open-minded, and be emotionally stable. These personal qualities were rated higher by the Lithuanian respondents when compared with the Latvian respondents. The personal qualities such as be attentive and be emotionally stable have been included in Top 3 both by the Latvian and Lithuanian adult educators.

Also the quantitative study results showed that from the future perspective there was no significant difference in adult educators' opinions on be altruistic, be open minded, and be emotionally stable between Latvian and Lithuanian respondents. However, there were the most significant and significant differences among the countries in scores obtained on be authentic, be humorous, be attentive, and be extroverted. According to the majority of the Lithuanian and Latvian respondents, the qualities such as be open minded and be emotionally stable will be more important in 2015. Furthermore, the majority of Latvian respondents thought that the importance of be authentic and be attentive will be higher in the future too. The qualitative study results indicated that open mindedness, optimism, emotional stability, sincerity, pro-activity, flexibility, sociability, tolerance, and morality (ethics) have been named both by the Latvian and Lithuanian adult educators as the main future-required personal qualities of the ACE learning facilitators. 


\section{Bibliography}

1. Bernhardsson, N., \& Lattke, S. (2011). Core competencies of adult learning facilitators in Europe. Findings from a transnational Delphi survey conducted by the project "Qualified to Teach". Retrieved from http://www.qf2teach.eu/assets/files/ Transnational\%20Report.pdf

2. Bron, A., \& Jarvis, P. (2008). Identities of adult educators: Changes in professionality. In E. Nuissl \& S. Lattke (Eds.), Qualifying adult learning professionals in Europe (pp. 33-44). W. Bertelsmann Verlag GmbH \& Co. KG.

3. Coryell, J. E. (2013). Collaborative, comparative inquiry and transformative crosscultural adult learning and teaching: A Western educator metanarrative and inspiring a global vision. Adult Education Quarterly, 63(4), 299-320. DOI: 10.1177/ 0741713612471420

4. Deggs, D., \& Miller, M. (2011). Developing community expectations: The critical role of adult educators. Adult Learning, 22(3), 25-30.

5. Ellis, J., \& Richardson, B. H. (2012). The development of national standards for adult educators in Namibia. International Review of Education, 58(3), 375-385.

6. Gartenschlaeger, U. (Ed.). (2009). European adult education outside the EU. Bonn, Germany: Institut für Internationale Zusammenarbeit des Deutschen VolkshochschulVerbandes ( $d v v$ international). Retrieved from http://www.eaea.org/doc/pub/ ALE_outside_Europe09.pdf Jarvis, P. (2012). Adult learning in the social context. Routledge Library Editions. Education. London: Routledge.

7. Nuissl, E., \& Lattke, S. (Eds.). (2008). Qualifying adult learning professionals in Europe. Bielefeld: W. Bertelsmann Verlag.

8. Nuissl, E., \& Egetenmeyer, R. (Eds.). (2010). Teachers and trainers in adult and lifelong learning: Asian and European perspectives. Frankfurt am Main: Peter Lang.

9. Research voor Beleid. (2008). ALPINE - Adult Learning Professions in Europe. A study of the current situation, trends and issues. Final report. Retrieved from http://ec.europa.eu/education/more-information/doc/adultprofreport_en.pdf

10. Research voor Beleid. (2010). Key competences for adult learning professionals. Contribution to the development of a reference framework of key competences for adult learning professionals. Final report. Retrieved from http://ec.europa.eu/education/ more-information/doc/2010/keycomp.pdf

11. Teresevičienè, M., \& Zuzevičiūtè, V. (2009). Towards the professionalisation of adult educator's activities: Challenges and perspectives. Monograph. Radom, Poland: The Publishing House of the Institute of Sustainable Technologies - National Research Institute, DVV international Project Office Poland.

\begin{tabular}{|c|c|}
\hline $\begin{array}{l}\text { Dr., professor } \\
\text { Vaiva Zuzevičiūtè }\end{array}$ & $\begin{array}{l}\text { Department of Humanities of the Faculty of Public } \\
\text { Security at Mykolas Romeris University, Lithuania } \\
\text { Email: vaiva.zuzeviciute@mruni.eu } \\
\text { Tel. +37061600292 }\end{array}$ \\
\hline Dr.paed. Svetlana Surikova & $\begin{array}{l}\text { Pedagogical Sciences of the Faculty of Education, } \\
\text { Psychology and Art of the University of Latvia } \\
\text { Email:Svetlana.surikova@lu.lv } \\
\text { Phone: + } 37126899707\end{array}$ \\
\hline
\end{tabular}

